\title{
Steam Explosions, Earthquakes, and Volcanic Eruptions- What's in Yellowstone's Future?
}

Jellowstone, one of the world's
largest active volcanic systems,
has produced several giant volcanic
eruptions in the past few million
years, as well as many smaller erup-
tions and steam explosions. Although
no eruptions of lava or volcanic ash
have occurred for many thousands of
years, future eruptions are likely. In
the next few hundred years, hazards
will most probably be limited to on-
going geyser and hot-spring activity,
occasional steam explosions, and
moderate to large earthquakes. To
better understand Yellowstone's
volcano and earthquake hazards and
to help protect the public, the U.S.
Geological Survey, the University of
Utah, and Yellowstone National Park
formed the Yellowstone Volcano Ob-
servatory, which continuously moni-
tors activity in the region.

Each year, millions of visitors come to admire the hot springs and geysers of Yellowstone, the Nation's first national park. Few are aware that these wonders are fueled by heat from a large reservoir of partially molten rock (magma), just a few miles beneath their feet. As this magma - which drives one of the world's largest volcanic systems-rises, it pushes up the Earth's crust beneath the Yellowstone Plateau.

Stresses in the crust produce movements on faults, causing earthquakes to occur. Thousands of small quakes are recorded each year by the seismographic network of the Yellowstone Volcano Observatory (YVO), a partnership of the U.S. Geological Survey (USGS), the University of Utah, and Yellowstone National Park. Faults and fractures also allow surface water to penetrate to depth and become heated, rising again to produce hydrothermal (hot water) features, such as geysers. Steam and hot

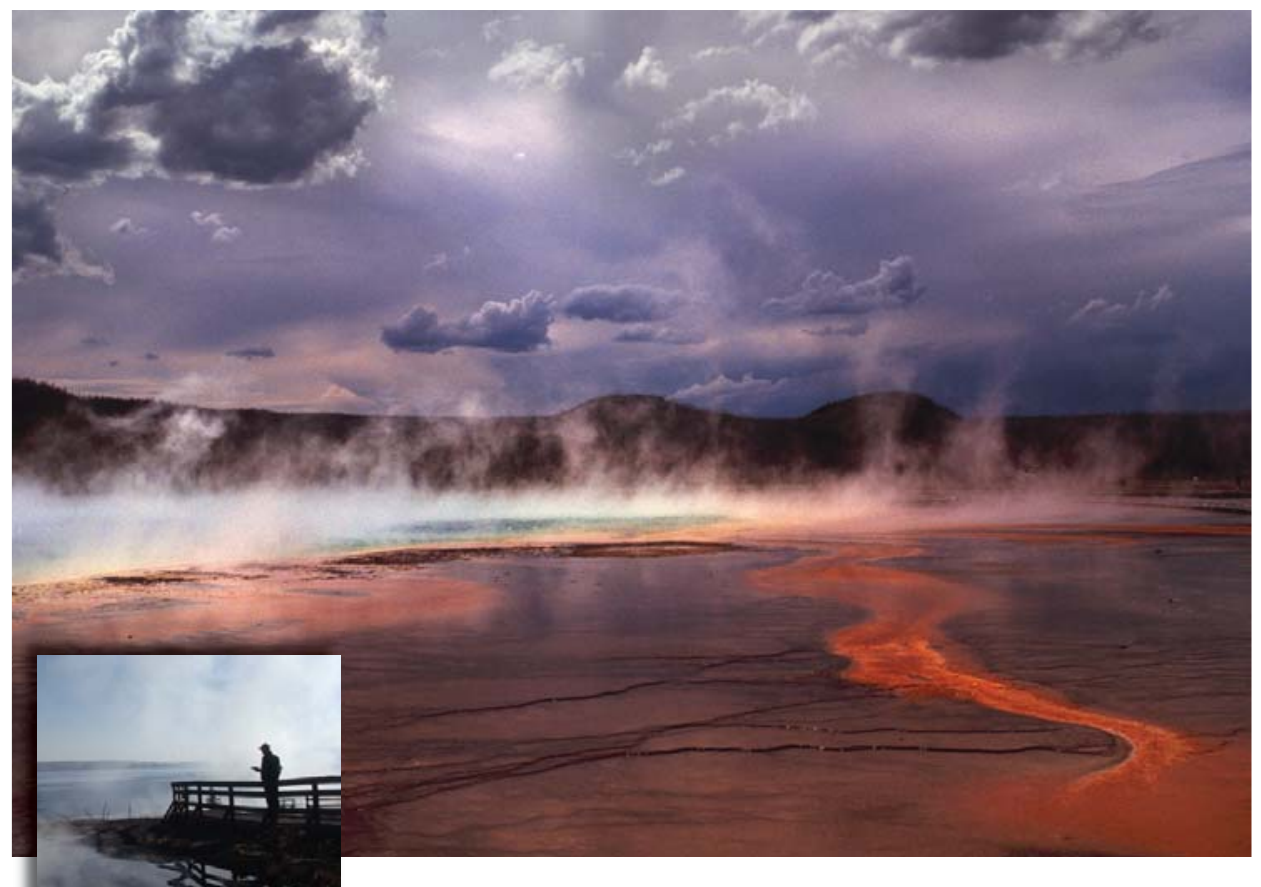

Midway Geyser Basin in Yellowstone National Park appears otherworldly beneath stormy skies. In the background, steam vigorously rises from the hot waters of Grand Prismatic Spring, known for its rainbow colors produced by thermophilic ("heat loving") organisms. Grand Prismatic is the largest hot spring in Yellowstone and the third largest in the world. This and other hydrothermal (hot water) features are among the main attractions for visitors to the park (inset photo). These features are fueled by heat from a large reservoir of partially molten rock (magma), just a few miles beneath Yellowstone, that drives one of the world's largest volcanic systems. (Photograph courtesy of Robert Fournier; inset courtesy of Susan Mayfield.)

water carry huge quantities of thermal energy to the surface from the magma chamber below. Continuing up-and-down ground motions on the Yellowstone Plateau reflect the migration of both hydrothermal fluids and magma below the surface.

Ground motions, earthquakes, and hydrothermal activity are all current manifestations of volcanic activity at Yellowstone. In the not-so-distant geologic past, Yellowstone has produced many major volcanic eruptions, which have repeatedly reshaped its natural wonders.

\section{Caldera-Forming Eruptions}

The Yellowstone region has produced three exceedingly large volcanic eruptions in the past 2.1 million years. In each of these cataclysmic events, enormous volumes of magma erupted at the surface and into the atmosphere as mixtures of red-hot pumice, volcanic ash (small, jagged fragments of volcanic glass and rock), and gas that spread as pyroclastic ("fire-broken") flows in all directions. Rapid withdrawal of such large volumes of magma from the subsurface then caused the ground to collapse, swallowing overlying mountains and creating broad cauldron-shaped volcanic depressions called "calderas."

The first of these caldera-forming eruptions 2.1 million years ago created a widespread volcanic deposit known as the Huckleberry Ridge Tuff, an outcrop of which can be viewed at Golden Gate, south of Mammoth Hot Springs. This titanic event, one of the five largest individual volcanic eruptions known anywhere on the Earth, formed a caldera more than 60 miles $(100 \mathrm{~km})$ across. 
A similar, smaller but still huge eruption occurred 1.3 million years ago. This eruption formed the Henrys Fork Caldera, located in the area of Island Park, west of Yellowstone National Park, and produced another widespread volcanic deposit called the Mesa Falls Tuff.

The region's most recent caldera-forming eruption 640,000 years ago created the 35 -mile-wide, 50 -mile-long ( 55 by $80 \mathrm{~km}$ ) Yellowstone Caldera. Pyroclastic flows from this eruption left thick volcanic deposits known as the Lava Creek Tuff, which can be seen in the south-facing cliffs east of Madison, where they form the north wall of the caldera. Huge volumes of volcanic ash were blasted high into the atmosphere, and deposits of this ash can still be found in places as distant from Yellowstone as Iowa, Louisiana, and California.

Each of Yellowstone's explosive calderaforming eruptions occurred when large volumes of "rhyolitic" magma accumulated at shallow levels in the Earth's crust, as little as 3 miles $(5 \mathrm{~km})$ below the surface. This highly viscous (thick and sticky) magma, charged with dissolved gas, then moved upward, stressing the crust and generating earthquakes. As the magma neared the surface and pressure decreased, the expanding gas caused violent explosions. Eruptions of rhyolite have been responsible for forming many of the world's calderas, such as those at Katmai National Park, Alaska, which formed in an eruption in 1912, and at Long Valley, California.

If another large caldera-forming eruption were to occur at Yellowstone, its effects would be worldwide. Thick ash deposits would bury vast areas of the United States, and injection of huge volumes of volcanic gases into the atmosphere could drastically affect global climate. Fortunately, the Yellowstone volcanic system shows no signs that it is headed toward such an eruption. The probability of a large caldera-forming eruption within the next few thousand years is exceedingly low.

\section{Lava Flows}

More likely in Yellowstone than a large explosive caldera-forming eruption is erup- tion of a lava flow, which would be far less devastating. Since Yellowstone's last calderaforming eruption 640,000 years ago, about 30 eruptions of rhyolitic lava flows have nearly filled the Yellowstone Caldera. Other flows of rhyolite and basalt (a more fluid variety of lava) also have been extruded outside the caldera. Each day, visitors to the park drive and hike across the lavas that fill the caldera, most of which were erupted since 160,000 years ago, some as recently as about 70,000 years ago. These extensive rhyolite lavas are very large and thick, and some cover as much as 130 square miles $\left(340 \mathrm{~km}^{2}\right)$, twice the area of Washington, D.C. During eruption, these flows oozed slowly over the surface, moving at most a few hundred feet per day for several months to several years, destroying everything in their paths.

Today, most of the landforms within the Yellowstone Caldera reflect the shapes of these young lava flows. Cliffs surrounding the Upper Geyser Basin near Old Faithful Geyser are the cooled steep flow fronts of

\section{VOLCANIC HISTORY AND RECENT SEISMIC ACTIVITY IN THE YELLOWSTONE REGION}

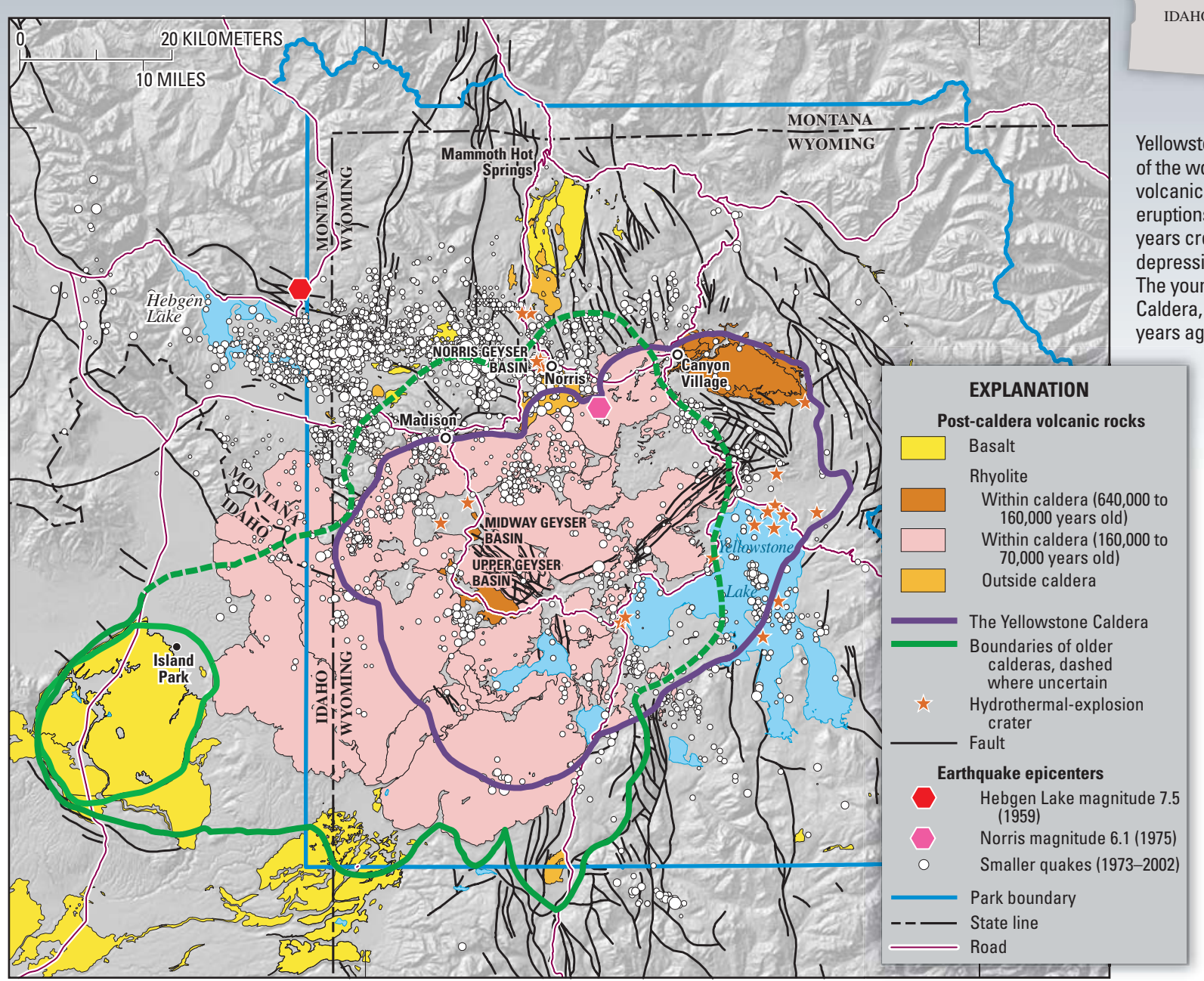

MONTANA

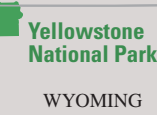

Yellowstone is home to one of the world's largest active canic systems. Cataclysmic created huge volcanic pressions called "calderas." youngest, the Yellowstone aldera, was formed 640,000 Since then, about 80 eruptions of rhyolite (thick, sticky lava) and basalt (more-fluid lava) have occurred. The caldera's interior is largely covered by rhyolites, most erupted in the past 160,000 years. Large hydrothermal (steam)-explosion craters formed in the past 14,000 years are located near Yellowstone Lake and in major geyser basins. Recent earthquakes (1973 to 2002) were concentrated between Hebgen Lake and the Norris Geyser Basin and along faults. 
once-slow-moving rhyolite lavas. Some narrow ridges and valleys on the CanyonNorris road are corrugations on the surface of a 110,000-year-old rhyolite flow. These roughly concentric ridges formed as the thick, pasty lava slowly oozed northeastward, wrinkling its surface. Within the caldera, rivers and streams commonly occupy the gaps between individual lava flows, and springs emerge at the edges of flows.

Any renewed volcanic activity at Yellowstone would most likely take the form of such mainly nonexplosive lava eruptions. An eruption of lava could cause widespread havoc in the park, including fires and the loss of roads and facilities, but more distant areas would probably remain largely unaffected.

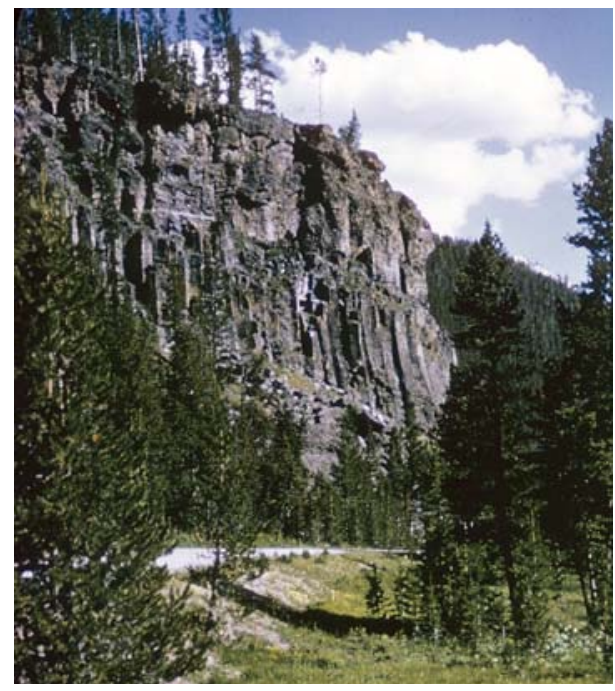

\section{Earthquakes}

From 1,000 to 3,000 earthquakes typically occur each year within Yellowstone National Park and its immediate surroundings. Although most are too small to be felt, these quakes reflect the active nature of the Yellowstone region, one of the most seismically active areas in the United States. Each year, several quakes of magnitude 3 to 4 are felt by people in the park.

Although some quakes are caused by rising magma and hot-ground-water movement, many emanate from regional faults related to crustal stretching and mountain building. For example, major faults along the Teton, Madison, and Gallatin Ranges pass through the park and likely existed long before the beginning of volcanism there. Movements along many of these faults are capable of producing significant earthquakes.

The most notable earthquake in Yellowstone's recent history occurred in 1959. Centered near Hebgen Lake, just west of the park, it had a magnitude of 7.5. This quake caused \$11 million in damage

Since its last cataclysmic volcanic eruption 640,000 years ago, the Yellowstone region has had about 40 eruptions of slow-moving lava flows of rhyolite (a variety of molten rock that is thick and sticky). Some of these flows cover more than 100 square miles, and many are very thick, like this approximately 180,000year-old rhyolite flow exposed at Obsidian Cliff. Although no lava has been erupted at Yellowstone for 70,000 years, future such eruptions are likely to occur. (USGS photograph by Robert Christiansen.) (equivalent to $\$ 70$ million in 2005 dollars) and killed 28 people, most of them in a landslide that was triggered by the quake.

Geologists conclude that large earthquakes like the Hebgen Lake event are unlikely within the Yellowstone Caldera itself, because subsurface temperatures there are high, weakening the bedrock and making it less able to rupture. However, quakes within the caldera can be as large as magnitude 6.5. A quake of about this size that occurred in 1975 near Norris Geyser Basin was felt throughout the region.

Even distant earthquakes can affect Yellowstone. In November 2002, the magnitude 7.9 Denali Fault earthquake struck central Alaska, 1,900 miles $(3,100 \mathrm{~km})$ northwest of Yellowstone. Because this quake's energy was focused toward the active Yellowstone volcanic and hydrothermal system, it triggered hundreds of small earthquakes there. The region's hydrothermal system is highly sensitive to quakes and undergoes significant changes in their wake. Earthquakes may have the potential to cause Yellowstone's hot-water system to destabilize and produce explosive hydrothermal eruptions.

\section{Hydrothermal Explosions}

The large magma reservoir beneath Yellowstone may have temperatures higher than $1,475^{\circ} \mathrm{F}\left(800^{\circ} \mathrm{C}\right)$, and the surrounding rocks are heated by it. Because of this, the average heat flow from the Earth's interior at Yellowstone is about 30 times greater

\section{EARTHOUAKES IN THE YELLOWSTONE REGION}

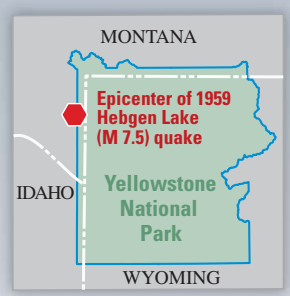

The Yellowstone National Park region produces about 2,000 earthquakes each year. Most of these quakes are too small to be felt, but they reflect the active nature of the region, one of the most seismically active areas in the United States.

The most powerful earthquake in Yellowstone's recent history occurred in 1959. This quake was centered near Hebgen Lake, just west of the park, and had a magnitude (M) of 7.5. The Hebgen Lake earthquake killed 28 people -26 in a huge landslide triggered by the quake - and caused $\$ 11$ million in damage (about $\$ 70$ million in 2005 dollars). Numerous structures and roads in the region were severely damaged when hillsides collapsed, gaping cracks opened in the ground, and large blocks of rock were displaced.

The Hebgen Lake quake caused widespread changes in Yellowstone-roads were closed throughout the area, some geysers stopped erupting, and others were newly formed or came back to life after years of dormancy. Also, the Old Faithful Inn was strongly shaken-pipes broke, a chimney collapsed, and the inn had to be evacuated.

Although quakes of this magnitude are rare in the Yellowstone region, they are certain to occur in the future. To better understand this hazard and help protect the public, scientists of the Yellowstone Volcano Observatory (YVO) continually monitor the region's seismic activity.

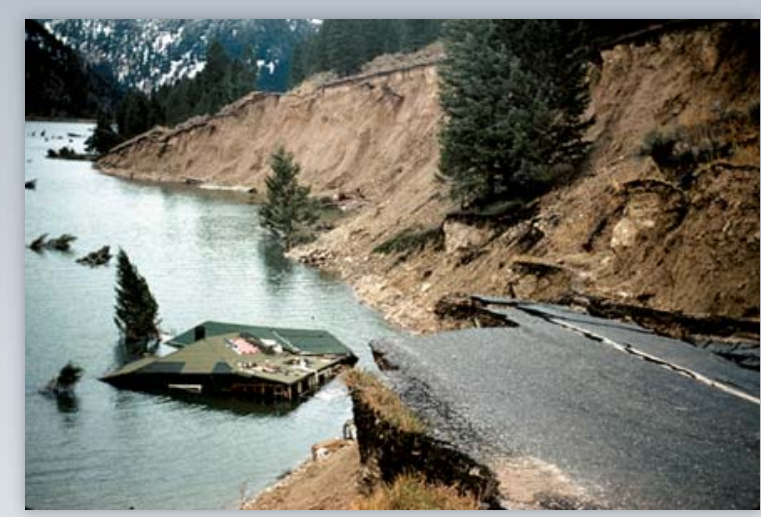

This house fell into Hebgen Lake during the 1959 earthquake and floated along the shore until it came to rest here. The owner of the house, then-70-year-old Mrs. Grace Miller, escaped only after kicking out her front door and leaping a 5-foot-wide ground crack as her house dropped into the lake. (USGS photograph by J.B. Hadley.) 
than that typical for areas elsewhere in the northern Rocky Mountains. As snowmelt and rainfall seep deep into the ground, they can absorb enough of this heat to raise the temperature of the ground water close to the boiling point. Geyser basins and other thermal areas in Yellowstone National Park are places where hot ground water has risen close to the surface. Research drilling at Yellowstone in the 1960s confirmed that the ground water beneath many of the park's thermal areas is very hot. At Norris Geyser Basin, water temperatures as high as $460^{\circ} \mathrm{F}\left(238^{\circ} \mathrm{C}\right)$ were recorded at depths of only 1,090 feet (332 m).

Because the boiling point of water increases with increasing pressure and pressure increases with depth, deep water can be hotter than boiling water near the surface. If the pressure that confines this deep water is reduced quickly, pockets of water may suddenly boil, causing an explosion as the water is converted to steam. Such activity drives the eruptions of geysers, like Old Faithful, which are repetitive releases of plumes of steam and water. Rarely, steam explosions are more violent and can hurl water and rock thousands of feet. In Yellowstone's geologic past, such violent events, called "hydrothermal explosions," have occurred countless times, creating new landscapes of hills and craters.

A recent and notable hydrothermal explosion occurred in 1989 at Porkchop Geyser in Norris Geyser Basin. The remains of this explosion are still clearly visible today as an apron of rock debris 15 feet $(5 \mathrm{~m})$ across surrounding Porkchop's central spring. In the 1880 s and early 1890 s, a series of powerful hydrothermal explosions and geyser eruptions occurred at Excelsior Geyser in the Midway Geyser Basin. Some of the explosions hurled large rocks as far as 50 feet $(15 \mathrm{~m})$.
Much larger hydrothermal explosions have occurred at Yellowstone in the recent geologic past. More than a dozen large hydrothermal-explosion craters formed between about 14,000 and 3,000 years ago, triggered by sudden changes in pressure of the hydrothermal system. Most of these craters are within the Yellowstone Caldera or along a north-south-trending zone between Norris and Mammoth Hot Springs.

The largest hydrothermal-explosion crater documented in the world is along the north edge of Yellowstone Lake in an embayment known as Mary Bay. This 1.5mile $(2.6 \mathrm{~km})$-diameter crater formed about 13,800 years ago and may have had several separate explosions in a short time interval. What specifically triggered these very large events is not firmly established, but earthquakes or a pressure release caused by melting glaciers or rapid changes in lake level may have been a significant factor.

\section{HYDROTHERMAL (STEAM) EXPLOSIONS AT YELLOWSTONE}

Geysers and hot springs are common expressions of a hydrothermal (hot water) system, but sometimes changes in "plumbing" result in large volumes of water suddenly flashing into steam, causing violent hydrothermal explosions. A large hydrothermal explosion can hurl water and rock thousands of feet and create new landscapes of hills and craters. In Yellowstone's geologic past, hydrothermal explosions have occurred countless times.

In 1881, Colonel Philetus W. Norris, Yellowstone National Park's second superintendent, witnessed a spectacular hydrothermal explosion at Excelsior Geyser in the Midway Geyser Basin. He described the aftermath as follows: "The pool was considerably enlarged, its immediate borders swept entirely clear of all movable rock, enough of which had been hurled or forced back to form a ridge from knee to breast high at a distance of from 20 to 50 feet [ 6 to $15 \mathrm{~m}$ ] from the ragged edge of the yawning chasm." After a series of such explosions that ended in the early 1890s, Excelsior, once the world's largest active geyser, became a quietly boiling hot spring. Except for several geyser eruptions in 1985, it has remained so ever since.

A more recent hydrothermal explosion occurred in 1989 at Porkchop Geyser in Norris Geyser Basin. The remains of this explosion are still clearly visible today as a 15 -foot ( $5 \mathrm{~m}$ )-diameter apron of rock debris surrounding Porkchop's central spring.

Much larger hydrothermal explo-

sions have occurred at Yellowstone in the recent geologic past. The greatest concentration of hydrothermal-explosion craters lies around the north end of Yellowstone Lake. These craters owe their origins to spectacular explosions thousands of years ago.

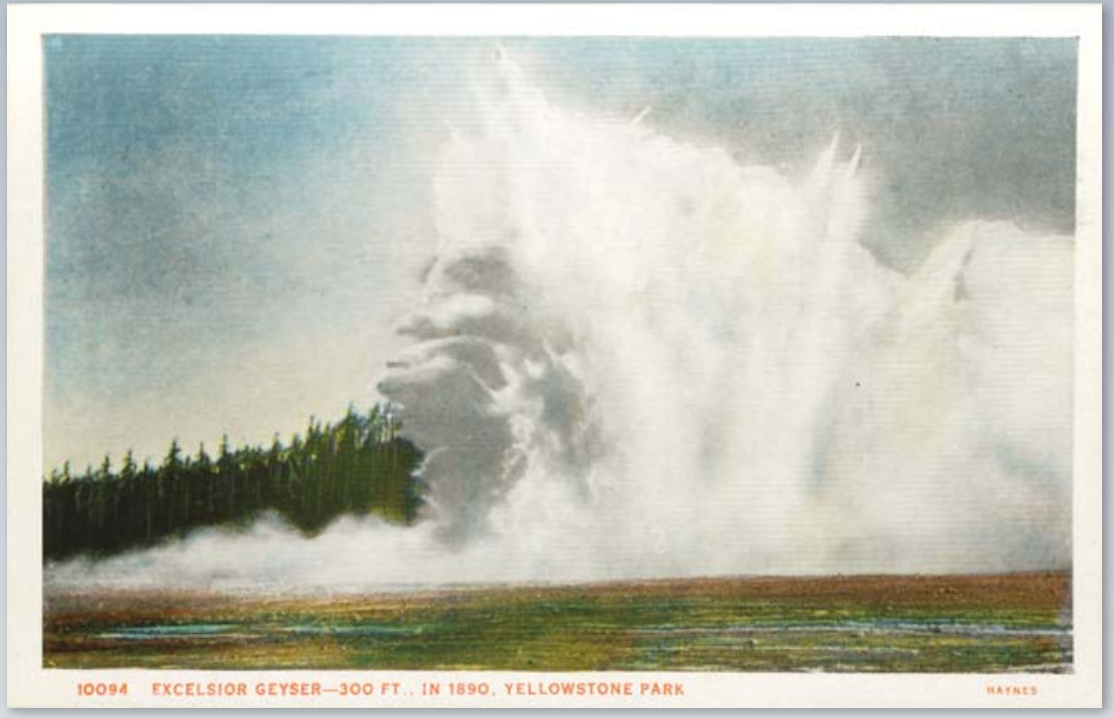

Excelsior Geyser erupted in a series of violent hydrothermal explosions in the 1880s and early 1890s; one of these eruptions is shown in this colorized postcard made from a photograph. These were the largest such events to occur in the Yellowstone region in historical times. (Original photograph by F. Jay Haynes, 1888; date on postcard is incorrect.)

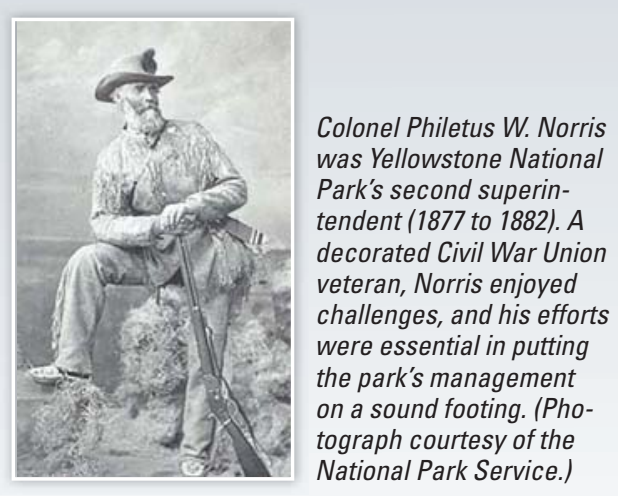

Yellowstone National Park research geologist Rick

Hutchinson examines rock debris thrown out in a 1989 hydrothermal explosion at Porkchop Geyser. [In March 1997, Hutchinson was killed in a snow avalanche while on duty inspecting thermal features in the park.] (Photograph courtesy of Robert Smith, University of Utah.) 


\section{PREHISTORIC CALDERA-FORMING ERUPTIONS OF YELLOWSTONE}

Eruptions of the Yellowstone volcanic system have included the two largest volcanic eruptions in North America in the past few million years; the third largest was at Long Valley in California and produced the Bishop ash bed. The biggest of the Yellowstone eruptions occurred 2.1 million years ago, depositing the Huckleberry Ridge ash bed. These eruptions left behind huge volcanic depressions called "calderas" and spread volcanic ash over large parts of North America (see map). If another large caldera-forming eruption were to occur at Yellowstone, its effects would be worldwide. Thick ash deposits would bury vast areas of the United States, and injection of huge volumes of volcanic gases into the atmosphere could drastically affect global climate. Fortunately, the Yellowstone volcanic system shows no signs that it is headed toward such an eruption in the near future. In fact, the probability of any such event occurring at Yellowstone within the next few thousand years is exceedingly low.

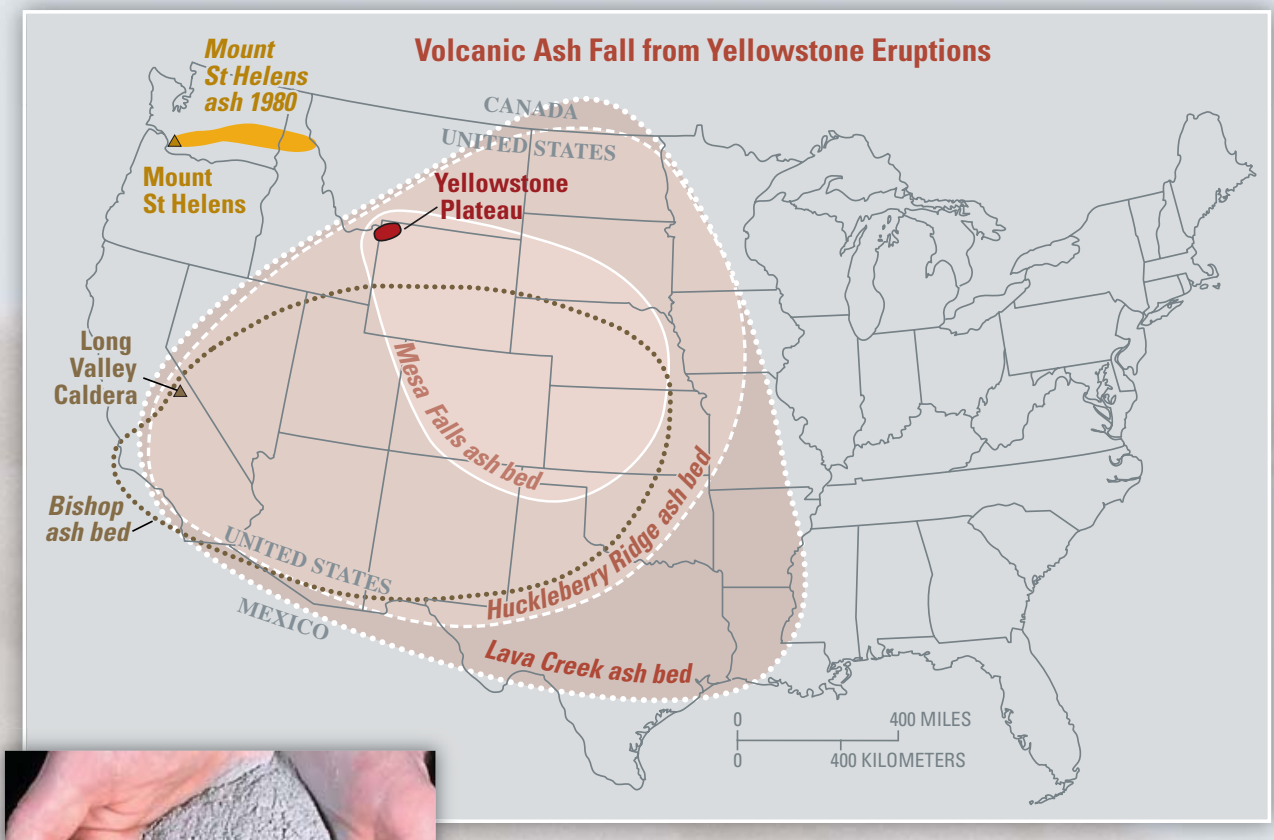

Volcanic ash, like this ash from the 1980 eruption of Mount St. Helens, is made up of tiny jagged particles of rock and glass (see inset, magnified about 200 times). Even a light dusting of volcanic ash can pose a health hazard to people and animals and damage crops, electronics, and machinery. Heavy ash fall, such as that from a large calderaforming eruption, would devastate the surrounding area and affected areas downwind. (USGS photographs.)

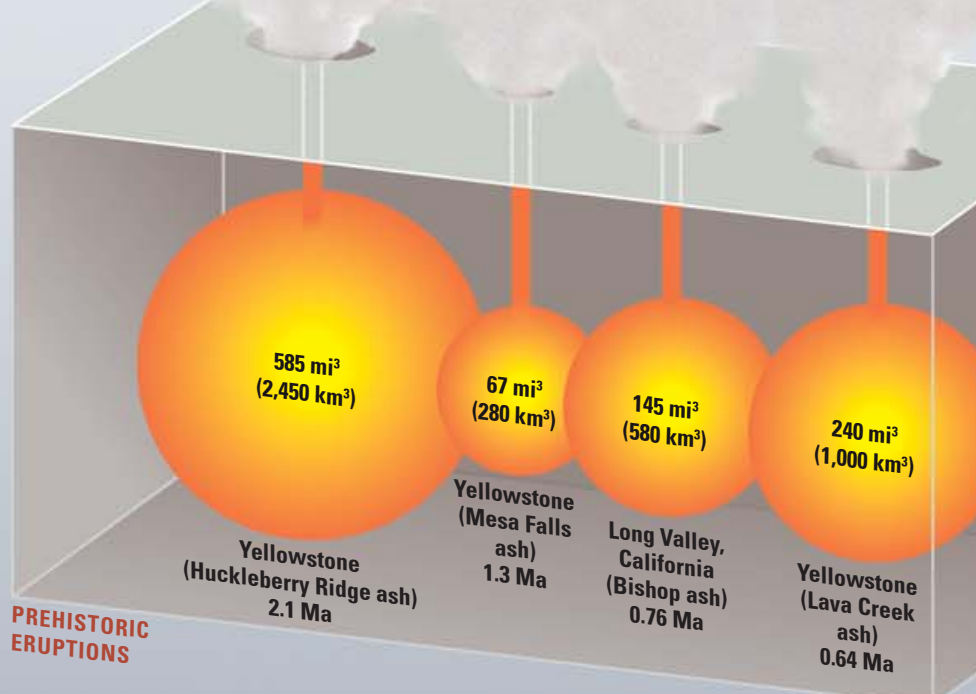

How Big Were the Yellowstone Eruptions?

Explosive eruptions are best compared by recalculating the volume of erupted volcanic ash and pumice (see photos) in terms of the original volume of molten rock (magma) released (shown in this diagram by orange spheres). On this basis, the 585 cubic miles $\left(\mathrm{mi}^{3}\right)$ of magma that was erupted from Yellowstone 2.1 million years ago (Ma) was nearly 6,000 times greater than the volume released in the 1980 eruption of Mount St. Helens, Washington, which killed 57 people and caused damage exceeding $\$ 1$ billion. Even the 1815 Tambora, Indonesia, eruption-the largest on Earth in the past two centuries - was more than five times smaller than the smallest of Yellowstone's three great prehistoric eruptions at 1.3 Ma.

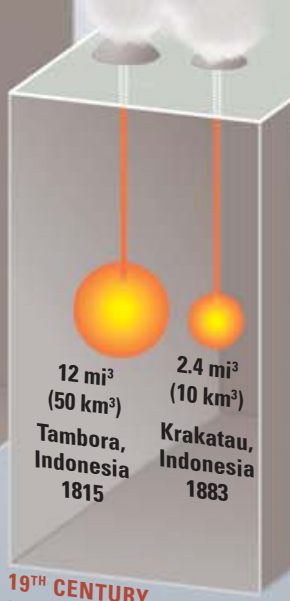

ERUPTIONS

$$
20^{\text {TH }} \text { CENTURY }
$$

ERUPTIONS 


\section{HAZARDOUS EVENTS AT YELLOWSTONE}

Scientists evaluate natural-hazard levels by combining their knowledge of the frequency and the severity of hazarddamaging hydrothermal explosions and earthquakes can occur several times a century. Lava flows and small volcanic eruptions occur only rarely - none in the past 70,000 years. Massive caldera-forming eruptions though the most potentially devastating of Yellowstone's hazards, are extremely rare-only three have occurred in the past several million years. U.S. Geological Survey, University of Utah, and National Park Service scientists with the Yellowstone Volcano Observatory (YVO) see no evidence that another such cataclysmic eruption will occur at Yellowstone in the foreseeable future. Recurrence intervals of these events are neither regular nor predictable. ous events. In the Yellowstone region,

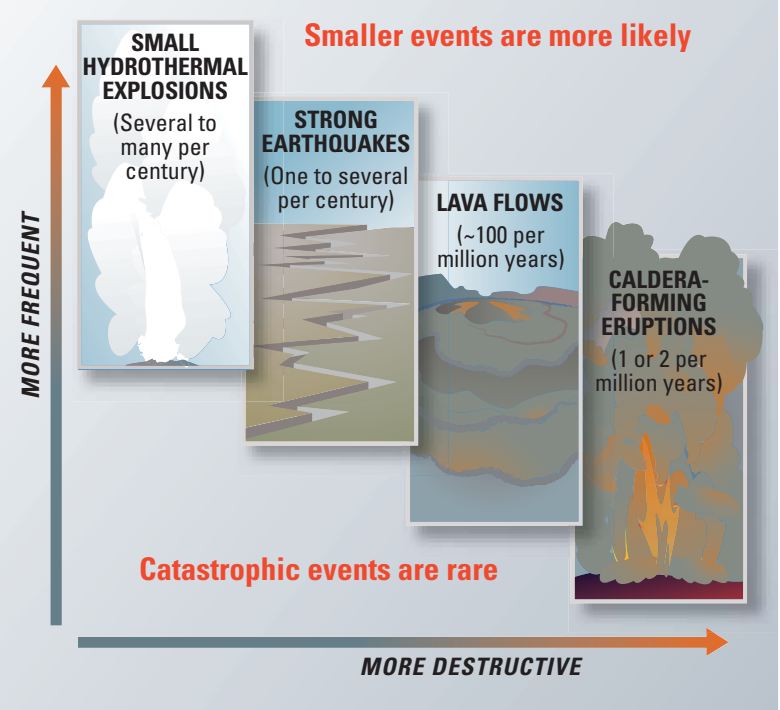

These very large and violent hydrothermal explosions are independent of associated volcanism. None of the large hydrothermal events of the past 16,000 years has been followed by an eruption of magma. The deeper magma system appears to be unaffected even by spectacular steam explosions and crater excavations within the overlying hydrothermal system.

Although large hydrothermal explosions are a feature of Yellowstone's recent geologic history, most explosions in historical times have been relatively small and have left craters at most a few yards across. For example, in early 2003, a long linear fissure appeared on a hillside above Nymph Lake, north of Norris Geyser Basin, venting steam and throwing bits of rock onto the surrounding hillside. Although most hydrothermal explosions in the park are small, their remains can be noticed by observant visitors and attest to the nearly continuous geologic activity at Yellowstone.

\section{How Dangerous Is Yellowstone?}

None of the events described abovecataclysmic caldera-forming eruptions, lava flows, large earthquakes, or major hydrothermal explosions - are common in Yellowstone. Although visitors to Yellowstone National Park may never experience them, some hazardous events are certain to occur in the future. Fortunately, systematic monitoring of Yellowstone's active volcanic and hydrothermal systems, including monitoring of earthquakes and ground deformation, is now carried out routinely by YVO scientists. This monitoring will allow YVO to alert the public well in advance of any future volcanic eruptions. Currently the ability to reli- ably predict large quakes or hydrothermal explosions, events more likely than a volcanic eruption, remains a challenge. However, changes in the patterns of ongoing seismicity or other indicators of possible geologic unrest are quickly reported to officials responsible for public safety in the National Park Service and other agencies.

Through continuous monitoring and research, YVO is greatly improving understanding of Yellowstone's volcanic, earthquake, and hydrothermal hazards. The work of USGS scientists with YVO is only part of the USGS Volcano Hazards Program's ongoing efforts to protect people's lives and property in all of the volcanic regions of the United States, including California, Hawaii, Alaska, and the Pacific Northwest.

Jacob B. Lowenstern, Robert L. Christiansen, Robert B. Smith, Lisa A. Morgan, and Henry Heasler

Edited by Peter H. Stauffer and James W. Hendley II Graphic design by Susan Mayfield and Sara Boore Banner design by Bobbie Myers

\section{COOPERATING ORGANIZATIONS \\ Yellowstone National Park}

University of Utah

$$
\begin{gathered}
\text { For more information contact: } \\
\text { Yellowstone National Park } \\
\text { http://www.nps.gov/yell/home.htm } \\
\text { or } \\
\text { U.S. Geological Survey } \\
\text { (650) 329-5227 } \\
\text { http://volcanoes.usgs.gov/yvo/ }
\end{gathered}
$$

See also Tracking Changes in Yellowstone's Restless Volcanic System (USGS Fact Sheet 100-03) and other USGS volcano Fact Sheets http://volcanoes.usgs.gov/Products/sproducts.html

This Fact Sheet and any updates to it are available online at http://pubs.usgs.gov/fs/2005/3024/
THE YELLOWSTONE VOLCANO OBSERVATORY

Increased scientific surveillance of Yellowstone in the past 30 years has detected unmistakable changes in its vast underground volcanic system, similar to historical changes observed at many other large calderas (volcanic depressions) in the world. To strengthen the capabilities of scientists to track and respond to changes in Yellowstone's activity, a fifth U.S. volcano observatory was created in 2001, complementing existing ones for Hawaii, Alaska, the Cascades, and Long Valley, California. The Yellowstone Volcano Observatory (YVO) is supported jointly by the U.S. Geological Survey, the University of Utah, and Yellowstone National Park.

The principal goals of YVO include: - Strengthening the monitoring system for tracking earthquake activity, uplift and subsidence, and changes in the hydrothermal (hot water) system;

- Assessing the long-term potential hazards of volcanism, earthquakes, and explosive hydrothermal activity in the Yellowstone region;

- Enhancing scientific understanding of active geologic and hydrologic processes occurring beneath Yellowstone and in the surrounding region of the Earth's crust; and

- Communicating new scientific results, the current status of Yellowstone's activity, and forecasts of potential hazardous hydrothermal explosions or volcanic eruptions to Yellowstone National Park staff, the public, and local, State, and Federal officials. Current real-time-monitoring data are online at http://volcanoes.usgs.gov/ yvo/monitoring.html .

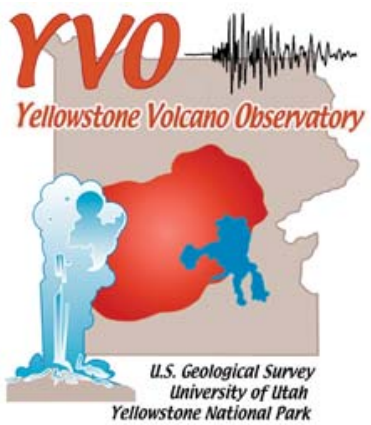

